\title{
HUBUNGAN KREATIVITAS GURU DAN LINGKUNGAN BELAJAR TERHADAP KEAKTIFAN SISWA KELAS III MIN JEJERAN BANTUL TAHUN AJARAN 2015/2016
}

\author{
Laelatul Badriah dan Rani Ayu Sholicha \\ PGMI STIA Alma Ata Yogyakarta
}

\begin{abstract}
ABSTRAK
Penelitian ini bertujuan untuk mengetabui bubungan kreativitas guru dan lingkungan belajar terhadap keaktifan siswa kelas III. Jenis penelitian menggunakan pendekatan kuantitatif, sedangkan desain penelitian ini menggunakan penelitian korelasional. Populasi dalam penelitian ini adalah seluruh guru kelas III dan selurub siswa kelas III. Teknik acak yang digunakan dalam pengambilan sampel ini adalab teknik acak sederbana (simple random sampling) dengan sistem undian. Sampel penelitian diambil sebanyak 50\% dari jumlab populasi dari selurub siswa, sehingga hasil dari pengambilan sampel tersebut sejumlah 55 siswa. Pengumpulan data dilakukan dengan metode angket dan dokumentasi. Teknik analisis data yang digunakan adalah analisis deskriptif dan inferensial, dalam analisis inferensial menggunakan korelasi product moment. Untuk menguji bipotesis korelasi variabel $x$ dan y menggunakan bantuan komputer program SPSS versi 16.0. Hasil penelitian menunjukkan adanya bubungan antara kreativitas guru dan lingkungan belajar terbadap keaktifan siswa dalam kategori cukup kuat. Hasil tersebut dibuktikan dari hasil perbitungan statistik dengan koefisien korelasi dan analisis regresi, dimana terdapat korelasi antara Ry. $x_{1}-x_{2}$ sebesar 0,450 pada taraf signifikan 5\% dengan sampel sebanyak 55 siswa. Nilai $r$ bitung $>$ nilai $r$ tabel yaitu 0,450>0,266 pada taraf signifikansi 5\% dengan kategori cukup kuat.
\end{abstract}

\begin{abstract}
This study aims to determine the relationship of creativity of teachers and the learning environment to the students' activity grade III. This type of research using quantitative approach, while the design of this research using correlational research. The population in this study are all teachers and all students of class III. Random techniques used in this sampling technique is simple random sampling (simple random sampling) by a lottery system. Samples were taken as much as 50\% of the total population of all students, so that the results of this sampling number of 55 students. The data collection is done by the questionnaire method and documentation. Data analysis technique used is descriptive and inferential analysis, the inferential analysis using product moment correlation. To test the hypothesis of correlation of variables $x$ and $y$ using SPSS version 16.0. The results showed the relationship between the creativity of teachers and the learning environment of the activity of students in a category is strong enough. These results evidenced from the results of statistical calculation with correlation coefficients and regression analysis, where there is a correlation between $R_{-}(\mathcal{Y}$. $\left.X_{-}(1) \cdot x_{-} 2\right)$ of 0.450 at significance level of $5 \%$ with a sample of 55 students. Value $r$ count $>r$ table value is $0.450>0.266$ at a significance level of $5 \%$ with strong enough category.
\end{abstract}

\section{PENDAHULUAN}

Pendidikan merupakan faktor yang penting bagi suatu negara, karena maju dan mundurnya suatu negara tidak terlepas dari peran pendidikan dalam membentuk sumber daya manusia yang berkualitas dan memiliki kecakapan dalam menguasai ilmu pengetahuan dan teknologi. Menurut Ki Hajar Dewantara yang dikutip oleh Wiji Sumarno dalam bukunya yang berjudul Dasar-Dasar Ilmu Pendidikan, mengartikan bahwa "Pendidikan adalah tuntutan bagi pertumbuhan anak-anak." Artinya, pendidikan menuntut segala kekuatan kodrat yang ada pada diri anak-anak, agar mereka sebagai manusia sekaligus anggota masyarakat dapat mencapai keselamatan dan kebahagiaan setinggi-tingginya. Dunia pendidikan tidak pernah lepas dari peran seorang guru. Guru adalah semua orang yang berwenang dan bertanggung jawab untuk membimbing dan membina 
anak didik, baik secara individual maupun kelompok, di sekolah maupun di luar sekolah. Secara sadar atau tidak, semua perilaku guru dalam proses pendidikan dan bahkan di luar proses pendidikan akan ditiru oleh siswanya. Oleh karena itu, guru harus betul-betul membawa siswanya kepada tujuan yang ingin dicapai. Guru harus mampu mempengaruhi siswanya, guru harus berpandangan luas dan memiliki kreatifitas yang tinggi.

Salah satu hal yang menunjukkan seseorang itu kreatif adalah memiliki kemampuan untuk menciptakan sesuatu yang baru atau memanfaatkan hal-hal yang ada untuk dikombinasikan sehingga memperoleh sesuatu yang baru. Demikian pula seorang guru, guru harus mampu memanfaatkan berbagai bahan di sekitarnya sebagai sarana pembelajaran. Guru dapat menggunakan metode yang bervariasi dalam mengajar atau memilih metode yang tepat untuk setiap bahan pembelajaran agar materi dapat tersampaikan dengan maksimal dan siswa tidak mudah bosan.

Selain guru yang kreatif, lingkungan belajar mempunyai peranan yang sangat penting dalam melaksanakan proses pembelajaran. Lingkungan belajar yang lengkap dengan sarana dan prasarana yang memadai tentunya akan lebih memudahkan peserta didik untuk mengikuti proses pembelajaran dan mengerjakan tugasnya dengan baik. Sebaliknya, akan ada hambatan dalam proses belajar apabila lingkungan belajar tidak layak untuk dijadikan tempat pembelajaran.

Lingkungan pendidikan atau lingkungan belajar dibedakan menjadi tiga golongan, antara lain: lingkungan keluarga, lingkungan sekolah, dan lingkungan masyarakat. Lingkungan belajar tersebut sangatlah mendukung dan berperan besar dalam membangun motivasi belajar dan keaktifan peserta didik serta berpengaruh terhadap prestasi belajar peserta didik.

Keberhasilan proses pembelajaran dapat dilihat dari hasil belajar siswa yang berupa nilai atau ditentukan dengan melihat keaktifan siswa dalam mengikuti pembelajaran. Keaktifan di sini bukan sekedar aktif atau ramai berlarian di dalam kelas, namun keaktifan yang berkualitas, yang ditandai dengan respon siswa, banyak pertanyaan atau jawaban, serta mampu menyelesaikan tugastugas yang diberikan oleh guru. Dengan keaktifan siswa dalam belajar maka hasil belajar siswa akan memuaskan. Selain itu pembelajaran yang aktif dimaksudkan untuk menjaga perhatian siswa agar tetap tertuju atau fokus terhadap proses pembelajaran.

Dari hasil pengamatan di Madrasah Ibtidaiyah Negri (MIN) Jejeran Bantul yang dilakukan pada empat kelas paralel terhadap guru serta siswa khususnya kelas III, di dalam proses belajar mengajar masih terdapat guru yang menggunakan metode ceramah dan jarang menggunakan media sehingga siswa terkesan lebih pasif, bahkan terlihat ada siswa yang asik berbincang dengan siswa lain, jarang ada siswa yang aktif dalam mengajukan pertanyaan saat guru menjelaskan materi. Saat diberi latihan soal siswa lebih sering bertanya sehingga terlihat bahwa siswa kurang memahami dengan materi yang telah dijelaskan. Di samping itu terdapat guru yang telah menggunakan metode yang membuat siswa aktif. Siswa diminta untuk mencari jawaban sendiri dan guru bertindak sebagai fasilitator dan membantu saat siswa mengalami kesulitan. Dengan metode ini siswa terlihat lebih aktif dibanding dengan penggunaan metode ceramah. Di sini terlihat bahwa guru yang kreatif dalam memilih metode dan melakukan variasi dalam menjelaskan materi kepada siswa akan lebih mendorong siswa untuk bertindak aktif. Sebaliknya guru yang kurang kreatif dan terpaku pada satu metode khususnya ceramah serta tidak memberikan kesempatan kepada siswa untuk ikut serta dalam proses pembelajaran akan mempengaruhi tersampainya meteri yang kurang maksimal dan membuat siswa menjadi lebih pasif.

Selain kreativitas guru, dalam menentukan kondisi lingkungan belajar khususnya ruang kelas dapat mempengaruhi keaktifan siswa dalam belajar. Lingkungan belajar yang kurang kondusif membuat siswa kurang tertarik mengikuti pembelajaran. Dari wawancara yang penulis lakukan terhadap salah satu guru kelas 3C Bapak Syamsul Huda, penataan ruang atau tata letak bangku siswa disusun sesuai dengan materi dan metode yang dipilih oleh guru sehingga 


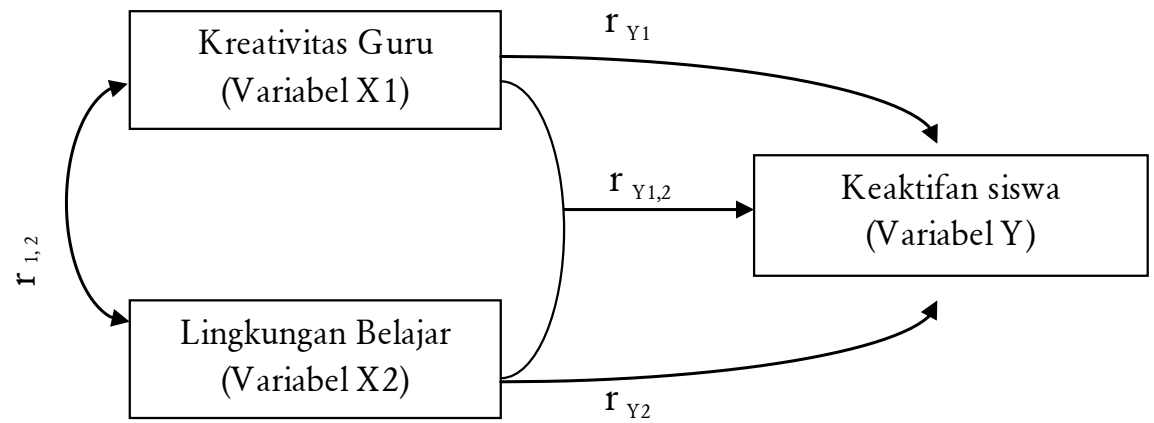

\section{Gambar 2. Desain Penelitian Hubungan Kreativitas Guru dan Lingkungan Belajar terhadap Keaktifan Siswa}

terdapat perubahan terhadap posisi tempat duduk yang membuat siswa tidak merasa bosan dan antusias dalam mengikuti pembelajaran. Hal serupa juga dikatakan oleh Ibu Siti Sofiyah guru kelas 3D, penyusunan tempat duduk disesuaikan dengan materi yang disampaikan. Namun pada kelas 3D Ibu Sofi lebih membebaskan siswa untuk mengatur letak tempat duduk sehingga kondisi lingkungan belajar yang disusun dengan keinginan siswa diharap dapat memicu keaktifan dan semangat siswa dalam belajar. Namun demikian, selain tata letak bangku siswa, sarana dan prasarana, kondisi lingkungan sekolah, kebersihan lingkungan belajar, sempitnya ruang kelas, panasnya suhu dalam kelas juga dapat mempengaruhi keaktifan siswa dalam belajar. Hasil observasi yang telah dilakukan oleh peneliti terhadap lingkungan belajar siswa di sekolah, MIN jejeran Bantul memiliki 2 kampus. Kampus satu yaitu sekolah utama yang terletak di Jalan Imogiri Timur dan kampus 2 terletak di daerah Demangan. Ruang kelas III terletak di kampus 2 yang kondisi sarana dan prasarana sekolah masih belum lengkap. Seperti tidak adanya ruang perpustakaan, tidak adanya ruang laboratorium, dan lain-lain. Oleh karena itu, lingkungan belajar harus diciptakan seoptimal mungkin agar siswa merasa nyaman dan betah untuk mengikuti pelajaran. Kondisi yang demikian akan membuat siswa antusias dalam mengikuti pembelajaran. Semakin siswa antusias dalam proses pembelajaran disitu siswa akan terdorong untuk aktif dalam mengikuti pembelajaran yang dilakukan oleh guru.

\section{METODE PENELITIAN}

Pendekatan yang digunakan dalam penelitian ini adalah pendekatan kuantitatif. Artinya, dalam penelitian ini banyak dituntut menggunakan angka mulai dari pengumpulan data, penafsiran terhadap data tersebut serta penampilan dari hasilnya.

Penelitian yang digunakan adalah penelitian korelasional. Suharsimi Arikunto mengemukakan penelitian korelasi adalah penelitian yang dilakukan oleh peneliti untuk mengetahui tingkat hubungan antara dua variabel atau lebih tanpa melakukan perubahan, tambahan atau manipulasi terhadap data yang memang sudah ada.

Dalam penelitian ini terdapat 3 variabel. Penelitian ini mengkaji hubungan kreativitas guru (X1) dan lingkungan belajar (X2) sebagai variabel bebas dengan keaktifan siswa $(\mathrm{Y})$ sebagai variabel terikat yang dapat digambarkan pada Gambar 2.

Subyek penelitian yang dijadikan penelitian adalah guru dan siswa kelas III MIN Jejeran Bantul Tahun Ajaran 2015/2016. Populasi dalam penelitian ini adalah keseluruhan guru kelas III yang berjumlah 4 orang dan siswa kelas III MIN Jejeran Bantul Tahun Pelajaran 2015/2016 yang berjumlah 109 siswa. ${ }^{1}$

Pengambilan sampel pada penelitian ini menggunakan teknik Proportioned Stratified Random Sampling yaitu pengambilan sampel dengan memperhatikan tingkatan dalam populasi. ${ }^{2}$ Pengambilan sampel didasarkan pada subyek

${ }^{1}$ Hasil observasi kelas 3 MIN Jejeran pada hari Jum'at- Sabtu tanggal 11-12 September 2015

${ }^{2}$ Sugiyono, Statistika Untuk Penelitian,........ hlm. 
Tabel 2. Kisi-kisi Angket Kreativitas Guru, Lingkungan Belajar dan Keaktifan Siswa

\begin{tabular}{|c|c|c|c|c|}
\hline \multirow{2}{*}{ Variabel } & \multirow{2}{*}{ Indikator } & \multicolumn{2}{|c|}{ No. Item } & \multirow{2}{*}{ Jumlah } \\
\hline & & Positif & Negatif & \\
\hline \multirow[t]{3}{*}{ Kreativitas guru } & $\begin{array}{l}\text { 1. guru memberikan kesempatan siswa untuk memilih } \\
\text { cara belajarnya sendiri }\end{array}$ & 1,2 & & 2 \\
\hline & 2. Guru mengembangkan aktivitas kelas & $3,4,5,6,7,8$ & & 6 \\
\hline & 3. Guru menilai pelaksanaan tugas atau kegiatan siswa & 9,10 & & 2 \\
\hline \multirow{3}{*}{$\begin{array}{c}\text { Lingkungan } \\
\text { belajar siswa } \\
\text { (sekolah) }\end{array}$} & 1. Lingkungan Fisik & 1,2 & 3 & 3 \\
\hline & 2. Lingkungan Sosial & 4,5 & & 2 \\
\hline & 3. Lingkungan Akademis & 6 & & 1 \\
\hline \multirow[t]{6}{*}{ Keaktifan siswa } & 1. Listening Activities & 1 & 2 & 2 \\
\hline & 2. Oral Activities & 3,6 & & 2 \\
\hline & 3. Emotional Activities & 4 & 5 & 2 \\
\hline & 4. Mental Activities & 7 & 8 & 2 \\
\hline & 5. Writing Activities & 9 & & 1 \\
\hline & Jumlah & 21 & 4 & 25 \\
\hline
\end{tabular}

dalam penelitian ini lebih dari 100 (seratus) orang, maka penulis mengambil 50\% dari keseluruhan siswa kelas III. Hal ini sesuai dengan pendapat Suharsimi Arikunto, yaitu:

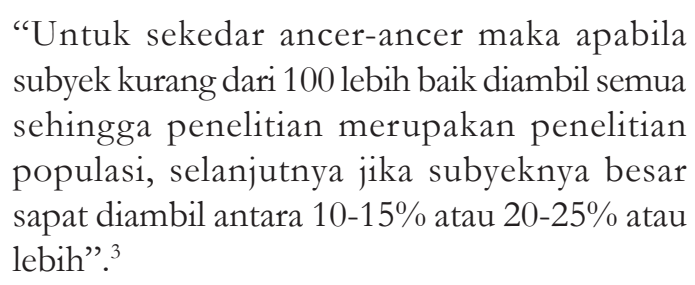

Teknik acak yang dilakukan dalam pengambilan sampel ini adalah dengan sampling acak sederhana yaitu peneliti mengambil $50 \%$ hasil dari pengambilan sampel adalah 55 siswa. Dengan melakukan undian seperti cara yang sudah umum dikenal.

Variabel penelitian adalah suatu atribut atau sifat nilai dari orang, obyek atau kegiatan yang mempunyai variasi tertentu yang ditetapkan peneliti untuk dipelajari dan kemudian ditarik kesimpulannya. ${ }^{4}$ Berdasarkan penelitian ini variabel penelitian terdiri atas dua variabel bebas dan satu variabel terikat.

1. Variabel bebas atau independent variable adalah variabel yang menjadi sebab timbulnya variabel

${ }^{3}$ Suharsimi Arikunto, Prosedur Penelitian Ilmiah........., hlm. 112

${ }^{4}$ Sugiyono, Metode Penelitian Administrasi, (Bandung: CV Alfabeta, 2006), hlm. 39 terikat. ${ }^{5}$ Variabel bebas pada penelitian ini adalah kreativitas guru (X1) dan lingkungan belajar (X2)

2. Variabel terikat atau dependent variable adalah variabel yang menjadi sebab akibat adanya variabel bebas. ${ }^{6}$ Keaktifan siswa $(Y)$ menjadi variabel terikat pada penelitian ini.

Dalam menggumpulkan data yang diperlukan peneliti menggunakan beberapa teknik pengumpulan data metode Angket dan metode dokumentasi. Sedangkan Instrumen penelitian adalah alat atau fasilitas yang digunakan oleh peneliti dalam mengumpulkan data agar pekerjaannya lebih mudah dan hasilnya lebih baik, dalam arti lebih cepat, lengkap, dan sistematis sehingga lebih mudah diolah. ${ }^{7}$

Dalam penelitian ini yang digunakan adalah dokumentasi dan angket/ kuesioner. Angket yang akan digunakan adalah angket tertutup berjumlah 25 soal. Adapun kisi-kisinya seperti pada Tabel 2.

Angket yang disebarkan kepada responden terdiri atas 4 alternatif jawaban. Adapun pemberian skor dari setiap jawabannya sebagai berikut:
${ }^{5}$ Ibid., hlm. 19
${ }^{6}$ Ibid., hlm. 19
${ }^{7}$ Ibid., hlm. 136 


\begin{tabular}{lcc}
$\begin{array}{c}\text { Tabel 3. Skor Angket Hubungan Kreativitas } \\
\text { Guru dan Lingkungan Belajar terhadap } \\
\text { Keaktifan Siswa }\end{array}$ \\
\hline \multicolumn{3}{c}{ Skor Pernyataan } \\
Alternatif Jawaban & Positif (+) & Negatif (-) \\
\hline Selalu (S) & 4 & 1 \\
Kadang-kadang (K) & 3 & 2 \\
Jarang (J) & 2 & 3 \\
Tidak Pernah (TP) & 1 & 4 \\
\hline
\end{tabular}

Instrumen penelitian dalam keabsahannya dilakukan dengan cara pengujian validitas dan reliabilitas. $^{8}$

\section{Uji Validitas Instrumen}

Data dikatakan valid apabila data tersebut terdapat kesamaan antara data yang terkumpul dengan data yang sesungguhnya terjadi pada obyek yang diteliti. ${ }^{9}$ Uji validitas menggunakan rumus Product Moment dari Pearson: ${ }^{10}$

$\operatorname{rxy}=\frac{\mathrm{n} \cdot\left(\sum \mathrm{xy}\right)-\left(\sum \mathrm{x}\right) \cdot\left(\sum \mathrm{y}\right)}{\sqrt{\left\{\mathrm{n} \cdot \sum \mathrm{x}^{2}-\left(\sum \mathrm{x}\right)^{2}\right\} \cdot\left\{\mathrm{n} \cdot \sum_{\mathrm{y}}^{2} \cdot\left(\sum \mathrm{y}\right)^{2}\right\}}}$

Keterangan:

rxy : koefisien korelasi

$\mathrm{x} \quad$ : skor yang diperoleh subyek dari seluruh item

y : skor total yang diperoleh dari seluruh item

$\Sigma \mathrm{x}$ : jumlah variabel $\mathrm{x}$

$\Sigma y \quad$ : jumlah variabel y

$\sum \mathrm{x}^{2}$ : jumlah kuadrat dalam skor distribusi $\mathrm{x}$

$\Sigma y^{2}$ : jumlah kuadrat dalam skor distribusi y

$\sum x y$ : jumlah hasil kali dari $\mathrm{x}$ dan y

$\mathrm{n} \quad$ : jumlah responden

Adapun perhitungan uji validitas dilakukan dengan menggunakan bantuan komputer program SPSS versi 16.0 dengan kriteria sebagai berikut:

a. Jika $r$ hitung $>\mathrm{r}$ tabel maka pernyataan tersebut valid.

\footnotetext{
${ }^{8}$ Sugiyono, Metode Penelitian Pendidikan.......... hlm. 173

'Sugiyono, Statistik Untuk Pendidikan, (Bandung: Alfabeta, 2010), hlm. 348

${ }^{10}$ Suharsimi Arikunto, Prosedur Penelitian Suatu Pendekatan Praktek........., hlm. 146
}

b. Jika $\mathrm{r}$ hitung $<\mathrm{r}$ tabel maka pernyataan tersebut tidak valid.

$\mathrm{R}$ hitung dapat dilihat pada kolom corrected item- total correlation.

Setelah melakukan penyebaran uji coba angket sebanyak 35 penyataan maka diperoleh data uji coba. Dan berdasarkan hasil rekapitulasi terdapat 10 pernyataan yang tidak valid, sehingga untuk penelitian hanya digunakan 25 butir pernyataan.

\section{Uji Reliabilitas Instrumen}

Dalam penelitian ini digunakan rumus Cronbach'a Alpha untuk menguji reliabilitas instrumen, sebab jenis datanya yaitu data interval yang diperoleh melalui angket.

Rumus Cronbacb'a Alpha ${ }^{11}$

$$
r_{11}=\frac{k}{(k-1)}\left(1-\frac{\sum a b^{2}}{a^{2} t}\right)
$$

Keterangan:

$$
\begin{aligned}
& \begin{array}{ll}
\mathrm{r} 11= & \text { Koefisien reliabilitas tes } \\
\mathrm{k}= & \text { Banyaknya butir item yang } \\
& \text { dikeluarkan dalam tes } \\
1 & =\text { Bilangan konstan } \\
\mathrm{ab}^{2}= & \text { Jumlah varian skor dari tiap-tiap } \\
& \text { butir item } \\
\mathrm{a}^{2} \mathrm{t}= & \text { Varian total }
\end{array}
\end{aligned}
$$

Koefisien reliabilitas yang dihasilkan, selanjutnya diinterpretasikan dengan menggunakan kriteria dari Guilford, yaitu: ${ }^{12}$

Tabel 5. Klasifikasi Koefisien Reliabilitas

\begin{tabular}{cc}
\hline Koefisien Reliabilitas & Interpretasi \\
\hline $0.00 \leq \mathrm{r} \leq 0.20$ & Sangat Rendah \\
$0.20 \leq \mathrm{r} \leq 0.40$ & Rendah \\
$0.40 \leq \mathrm{r} \leq 0.60$ & Sedang/ Cukup \\
$0.60 \leq \mathrm{r} \leq 0.80$ & Tinggi \\
$0.80 \leq \mathrm{r} \leq 1.00$ & Sangat Tinggi \\
\hline
\end{tabular}

Dalam penelitian ini, uji reliabilitas menggunakan bantuan komputer dengan program

\footnotetext{
${ }^{11}$ Anas Sudijono, Pengantar Evaluasi Pendidikan, (Jakarta: PT Raja Grafindo Persada, 1996), hlm. 208

${ }^{12}$ Irwanto, Komputasi Data Statistik Untuk Penelitian, (Pengolahan dan Analisis Data Penelitian dengan Ms Excel dan SPSS, (Yogyakarta: CV Budi Utama, 2012), hlm. 9
} 
SPSS versi 16.0. butir pernyataan yang sudah dinyatakan valid dalam uji validitas ditentukan reliabilitasnya dengan kriteria sebagai berikut:

a. Jika r alpha $>$ r tabel maka reliabel.

b. Jika r alpha $<$ r tabel maka tidak reliabel.

Berdasarkan pengujian reliabilitas dengan program SPSS versi 16.0. didapat hasil sebagai berikut:

Tabel 6. Tabel Hasil Uji Reliabilitas Instrumen

\begin{tabular}{cc}
\hline Cronbach's Alpha & N of Items \\
\hline 0.974 & 25 \\
\hline
\end{tabular}

Pada 25 butir pernyataan yang diberikan dengan tingkat signifikansi 5\% dan r alpha $=$ 0.974; ini berarti $\mathrm{r}$ alpha $>\mathrm{r}$ tabel yaitu 0,266 dan koefisien reliabilitasnya berada pada 0.80 $\leq 0.974 \leq 1.00$, berarti termasuk kategori sangat tinggi. Sehingga dapat dinyatakan bahwa kuesioner tersebut telah reliabel dan dapat disebarluaskan kepada responden sebagai instrumen penelitian.

Analisis data yang digunakan dalam penelitian ini ada dua macam, yaitu analisis deskriptif dan inferensial. Analisis deskriptif yaitu teknik analisis yang bertujuan untuk memberikan deskripsi mengenai objek penelitian berdasarkan data dari variabel yang diperoleh dari kelompok subjek yang diteliti dan tanpa bermaksud untuk membuat kesimpulan (pengujian hipotesis) yang berlaku untuk umum atau generalisasi. ${ }^{13}$ Teknik analsis inferensial yaitu teknik analisis data yang dimaksudkan untuk mengambil kesimpulan dengan menguji hipotesis. ${ }^{14}$ Dalam analisis inferensial, digunakan teknik analisis Product moment, dengan rumus: ${ }^{15}$

$$
\operatorname{rxy}=\frac{\mathrm{n} \cdot\left(\sum \mathrm{xy}\right)-\left(\sum \mathrm{x}\right) \cdot\left(\sum \mathrm{y}\right)}{\sqrt{\left\{\mathrm{n} \cdot \sum \mathrm{x}^{2}-\left(\sum \mathrm{x}\right)^{2}\right\} \cdot\left\{\mathrm{n} \cdot \sum_{\mathrm{y}}^{2} \cdot\left(\sum \mathrm{y}\right)^{2}\right\}}}
$$

\footnotetext{
208

${ }^{13}$ Sugiyono, Metode Penelitian Pendidikan.........., hlm.

${ }^{14}$ Sugiyono, Metode Penelitian Pendidikan.........., hlm. 208

${ }^{15}$ Suharsimi Arikunto, Prosedur Penelitian Suatu Pendekatan Praktek........., hlm. 146
}

Keterangan:

rxy : koefisien korelasi

$\mathrm{x} \quad$ : skor yang diperoleh subyek dari seluruh item

y : skor total yang diperoleh dari seluruh item

$\Sigma \mathrm{x}$ : jumlah variabel $\mathrm{x}$

$\Sigma y \quad$ : jumlah variabel y

$\sum \mathrm{x}^{2}$ : jumlah kuadrat dalam skor distribusi $\mathrm{x}$

$\Sigma y^{2}$ : jumlah kuadrat dalam skor distribusi y

$\sum x y$ : jumlah hasil kali dari $\mathrm{x}$ dan $\mathrm{y}$

n : jumlah responden

Karena dalam penelitian ini terdapat dua variabel independent maka untuk menguji hipotesis digunakan korelasi ganda (multiple correlation) dengan menggunakan rumus: ${ }^{16}$

$$
R_{y, x_{1} x_{2}}=\sqrt{\frac{r_{y x_{1}}{ }^{2}+r_{y x_{2}}{ }^{2}-2 r_{y x_{1}} r_{y x_{2}}}{1-r_{x x x_{2}}{ }^{2}}}
$$

Keterangan:

$\operatorname{Ryx}_{1} \mathrm{x}_{2}$ : Korelasi antara variabel dengan secara bersama-sama dengan variabel y

$\operatorname{ryx}_{1} \quad$ : Korelasi Product Moment antara dengan y

$\operatorname{ryx}_{2} \quad$ : Korelasi Product Moment antara dengan y

$\operatorname{rx}_{1} \mathrm{x}_{2} \quad$ : Korelasi Product Moment antara dengan

Untuk menguji hipotesis korelasi variabel $\mathrm{x}$ dan y menggunakan bantuan komputer program SPSS versi 16.0. Kuat lemahnya koefisien korelasi dapat diinterpretasikan dengan pedoman berikut:

Tabel 7. Pedoman Untuk Memberikan Interpretasi Koefisien Korelasi ${ }^{17}$

\begin{tabular}{cc}
\hline Interval Korelasi & Tingkat Hubungan \\
\hline $0,00-0,199$ & Sangat Rendah \\
$0,20-0,399$ & Rendah \\
$0,40-0,599$ & Cukup \\
$0,60-0,799$ & Kuat \\
$0,80-1,00$ & Sangat Kuat \\
\hline
\end{tabular}

${ }^{16}$ Sugiyono, Statistika Untuk Penelitian, (Bandung: Alfabeta, 2013), hlm. 233

${ }^{17}$ Sugiyono, Metode Penelitian Pendidikan......... , hlm. 257 
Untuk mengetahui seberapa besar persentase kontribusi simultan antar variabel dapat diketahui dengan rumus $\mathrm{R}^{2}$ x $100 \% .{ }^{18}$

Ketentuan pengujian hipotesis adalah sebagai berikut: Ha ditolak apabila harga $\mathrm{r}$ hitung kurang dari $\mathrm{r}$ tabel, Ha diterima apabila $\mathrm{r}$ hitung lebih besar atau sama dengan $r$ tabel, dengan taraf kesalahan $5 \%$.

Hipotesis statistik dalam penelitian ini adalah:

Ho : $=0$

$\mathrm{Ha}: \neq 0$ (= simbol yang menunjukkan kuatnya hubungan)

Artinya:

Ho: tidak adanya hubungan antara kreativitas guru dan lingkungan belajar terhadap keaktifan siswa di MIN Jejeran.

$\mathrm{Ha}$ : adanya hubungan antara kreativitas guru dan lingkungan belajar terhadap keaktifan siswa di MIN Jejeran

\section{HASIL PENELITIAN DAN PEMBAHASAN Hasil Penelitian}

Data penelitian dilakukan perhitungan dengan menggunakan bantuan komputer SPSS versi 16.0. Adapun hasil yang diperoleh sebagai berikut:

\begin{tabular}{cccc}
\multicolumn{3}{c}{ Tabel 11. Analisis Deskriptif Statistik } \\
Kreativitas Guru, Lingkungan Belajar dan \\
\multicolumn{4}{c}{ Keaktifan Siswa } \\
\hline Variabel & Kreativitas & Lingkungan & Keaktifan \\
& Guru & Belajar & Siswa \\
\hline N & 55 & 55 & 55 \\
Luas Sebaran Nilai & 15 & 13 & 21 \\
Nilai Terendah & 25 & 10 & 16 \\
Nilai Tertinggi & 39 & 22 & 36 \\
Rata-rata Hitung & 31.95 & 16.11 & 28.42 \\
Standar Deviasi & 2.825 & 2.740 & 4.184 \\
\hline
\end{tabular}

Dari tabel di atas menunjukkan bahwa jumlah responden adalah 55 siswa, untuk variabel kreativitas guru memiliki luas sebaran nilai 15 , nilai terendah 25, nilai tertinggi 39, rata-rata hitung/Mean sebesar 31.95 , dan standar deviasinya yaitu 2.825 .

${ }^{18}$ Riduwan dkk, Pengantar Statistika Untuk Penelitian: Pendidikan, Sosial, Komunikasi, Ekonomi dan Bisnis, (Bandung: Alfabetas, 2011), hlm. 91
Untuk variabel lingkungan belajar memiliki luas sebaran nilai 13 , nilai terendah 10 , nilai tertinggi 22, rata-rata hitung/ Mean sebesar 16.11, dan standar deviasinya yaitu 2,740.

Selanjutnya, untuk variabel keaktifan siswa memiliki luas sebaran nilai 21, nilai terendah 16, nilai tertinggi 36, rata-rata hitung/Mean sebesar 28.42, dan standar deviasinya yaitu 4.184.

\section{Kreativitas Guru}

Guru memberikan kesempatan siswa untuk memilih cara belajar

Tanggapan dari siswa kelas III MIN Jejeran terhadap indikator ini adalah sebagai berikut:

Tabel 12. Guru Memberikan Kesempatan Siswa untuk Memilih Cara Belajar

\begin{tabular}{|c|c|c|c|c|}
\hline Pernyataan & $\begin{array}{l}\text { No. } \\
\text { Item }\end{array}$ & Alternatif Jawaban & Frek & $\begin{array}{c}\text { Persentase } \\
(\%)\end{array}$ \\
\hline \multirow{4}{*}{ Positif } & \multirow{4}{*}{1,2} & Selalu & 38 & $34.55 \%$ \\
\hline & & Kadang-kadang & 64 & $58.18 \%$ \\
\hline & & Jarang & 0 & $0 \%$ \\
\hline & & Tidak pernah & 8 & $7.27 \%$ \\
\hline \multicolumn{3}{|c|}{ Jumlah } & 110 & $100 \%$ \\
\hline
\end{tabular}

Tabel 12 menunjukkan bahwa 58.18\% responden menjawab kadang-kadang guru memberikan kesempatan siswa untuk memilih cara belajarnya sendiri yaitu dengan cara belajar mandiri maupun belajar berkelompok. Guru biasanya memberikan kesempatan belajar kepada siswa dengan menyesuaikan mata pelajaran serta materi yang sedang diberikan kepada siswa.

Guru mengembangkan aktivitas kelas

Tanggapan dari siswa kelas III MIN Jejeran terhadap indikator ini adalah sebagai berikut:

Tabel 13. Guru Mengembangkan Aktivitas Kelas

\begin{tabular}{|c|c|c|c|c|}
\hline Pernyataan & $\begin{array}{l}\text { No. } \\
\text { Item }\end{array}$ & $\begin{array}{c}\text { Alternatif } \\
\text { Jawaban }\end{array}$ & Frekuensi & $\begin{array}{c}\text { Persentase } \\
(\%)\end{array}$ \\
\hline \multirow{4}{*}{ Positif } & \multirow{4}{*}{$\begin{array}{c}3,4,5 \\
6,7,8\end{array}$} & Selalu & 135 & $40.91 \%$ \\
\hline & & Kadang-kadang & 143 & $43.33 \%$ \\
\hline & & Jarang & 41 & $12.43 \%$ \\
\hline & & Tidak pernah & 11 & $3.33 \%$ \\
\hline \multicolumn{3}{|c|}{ Jumlah } & 330 & $100 \%$ \\
\hline
\end{tabular}

Tabel di atas menunjukkan $43.33 \%$ responden mejawab kadang-kadang guru mengembangkan aktivitas kelas meliputi penggunaan alat peraga dalam menjelaskan materi, menyampaikan materi dengan cara yang menarik sehingga materi mudah 
Tabel 14. Guru Menilai Pelaksanaan Tugas Atau Kegiatan Siswa

\begin{tabular}{|c|c|c|c|c|}
\hline Pernyataan & $\begin{array}{l}\text { No. } \\
\text { Item }\end{array}$ & $\begin{array}{c}\text { Alternatif } \\
\text { Jawaban }\end{array}$ & Frekuensi & $\begin{array}{c}\text { Persentase } \\
(\%)\end{array}$ \\
\hline \multirow{4}{*}{ Positif } & \multirow{4}{*}{9,10} & Selalu & 51 & $46.36 \%$ \\
\hline & & Kadang-kadang & 43 & $39.09 \%$ \\
\hline & & Jarang & 6 & $5.45 \%$ \\
\hline & & Tidak pernah & 10 & $9.10 \%$ \\
\hline \multicolumn{3}{|c|}{ Jumlah } & 110 & $100 \%$ \\
\hline
\end{tabular}

dimengerti, mengajak siswa bernyanyi/yel-yel agar pembelajaran menyenangkan, menegur saat ada siswa yang ramai, memberi hadiah kepada siswa yang berprestasi serta memberi pekerjaan rumah untuk siswa.

Penggunaan alat peraga digunakan untuk mempermudah siswa dalam menerima materi yang diajarkan serta menumbuhkan minat siswa dalam belajar. Guru mengajak siswa benyanyi atau yel-yel dalam pembelajaran. Biasanya guru mengajak siswa menyerukan yel-yel diawal pembelajaran untuk membangkitkan semangat belajar dan ditengah pembelajaran apabila guru melihat siswa bosan dalam pembelajaran. Guru juga menegur siswa saat ada yang ramai supaya tidak mengganggu konsentrasi siswa yang lain. Pemberian hadiah kepada siswa dilakukan oleh guru supaya siswa antusias dalam mengikuti pembelajaran. Terkadang guru memberi hadiah apabila terdapat siswa yang memperoleh nilai tertinggi.

Guru menilai pelaksanaan tugas atau kegiatan siswa

Tanggapan dari siswa kelas III MIN Jejeran terhadap indikator ini seperti pada Tabel 14.

Berdasarkan Tabel 14. 46.36\% responden menjawab selalu yaitu guru selalu menilai dan memberikan catatan perbaikan terhadap tugas yang telah diselesaikan siswa. Pemberian penilaian dilakukan agar guru mengetahui seberapa besar keberhasilan siswa dalam mengikuti pembelajaran. Guru biasanya langsung memberikan nilai kepada siswa. Apabila terdapat siswa yang memiliki nilai kurang, guru meminta siswa untuk melakukan perbaikan.

Dari ketiga indikator di atas dapat disimpulkan bahwa kreativitas guru memiliki nilai persentase nilai tertinggi sebagai berikut:
Tabel 15. Persentase Kreativitas Guru

\begin{tabular}{|c|c|c|c|}
\hline \multicolumn{2}{|r|}{ Indikator } & Jawaban & Persentase \\
\hline a. & $\begin{array}{l}\text { Guru memberikan kesempatan } \\
\text { kepada siswa untuk memilih cara } \\
\text { belajarnya }\end{array}$ & $\begin{array}{l}\text { Kadang- } \\
\text { kadang }\end{array}$ & $58,18 \%$ \\
\hline b. & $\begin{array}{l}\text { Guru mengembangkan aktivitas } \\
\text { kelas }\end{array}$ & $\begin{array}{l}\text { Kadang- } \\
\text { kadang }\end{array}$ & $43,33 \%$ \\
\hline c. & $\begin{array}{l}\text { Guru menilai pelaksanaan tugas/ } \\
\text { kegiatan siswa }\end{array}$ & Selalu & $46.36 \%$ \\
\hline
\end{tabular}

Variabel kreativitas guru dapat dikelompokkan dalam 5 patokan kategori sesuai dengan norma skala lima sebagai berikut:

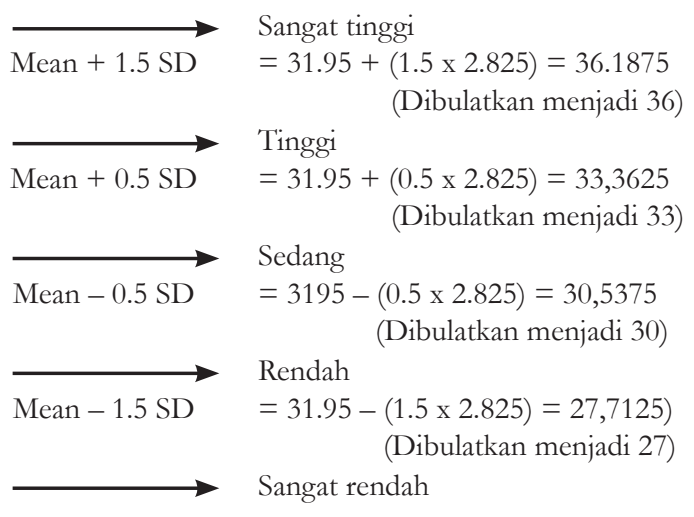

Sehingga diperoleh data sebagai berikut:

Tabel 16. Kategori Kreativitas Guru

\begin{tabular}{lcc}
\hline \multicolumn{1}{c}{ Kategori } & Rentangan Skor & Pembulatan \\
\hline Sangat Tinggi & $36.19-39.00$ & $36-39$ \\
Tinggi & $33.36-36.18$ & $33-35$ \\
Sedang/Cukup & $30.54-33.35$ & $30-32$ \\
Rendah & $27.71-30.53$ & $27-29$ \\
Sangat Rendah & $25.00-27.70$ & $25-26$ \\
\hline
\end{tabular}

Berdasarkan kategori tersebut, data variabel kreativitas guru siswa kelas III MIN Jejeran Bantul yaitu sebagai berikut:

Tabel 17. Rekapitulasi Kategori Kreativitas Guru

\begin{tabular}{clcc}
\hline No & Kategori & Frekuensi $(\mathrm{F})$ & Persentase $(\%)$ \\
\hline 1 & Sangat Tinggi & 8 & $14.54 \%$ \\
2 & Tinggi & 23 & $41.82 \%$ \\
3 & Sedang/Cukup & 17 & $30.91 \%$ \\
4 & Rendah & 6 & $10.91 \%$ \\
5 & Sangat Rendah & 1 & $1.82 \%$ \\
\hline Total & & 55 & $100 \%$ \\
\hline
\end{tabular}

Mean (nilai rata-rata) kreativitas guru MIN Jejeran Bantul adalah 31.95. Nilai tersebut jika diinterpretasikan pada tabel 19, maka kreativitas guru kelas III MIN Jejeran berada pada kategori sedang/cukup. Apabila disesuaikan dengan 
Tabel 18. Lingkungan Fisik

\begin{tabular}{|c|c|c|c|c|}
\hline Pernyataan & $\begin{array}{l}\text { No. } \\
\text { Item }\end{array}$ & $\begin{array}{c}\text { Alternatif } \\
\text { Jawaban }\end{array}$ & Frekuensi & $\begin{array}{c}\text { Persentase } \\
(\%)\end{array}$ \\
\hline \multirow{5}{*}{ Positif } & \multirow{5}{*}{1,2} & Selalu & 6 & $5.45 \%$ \\
\hline & & Kadang-kadang & 39 & $35.45 \%$ \\
\hline & & Jarang & 50 & $45.45 \%$ \\
\hline & & Tidak pernah & 15 & $13.65 \%$ \\
\hline & & Jumlah & 110 & $100 \%$ \\
\hline \multirow{5}{*}{ Negatif } & \multirow{5}{*}{3} & Selalu & 7 & $12.73 \%$ \\
\hline & & Kadang-kadang & 15 & $27.27 \%$ \\
\hline & & Jarang & 7 & $12.73 \%$ \\
\hline & & Tidak pernah & 26 & $47.27 \%$ \\
\hline & & Jumlah & 55 & $100 \%$ \\
\hline
\end{tabular}

hasil angket siswa maka kreativitas guru masuk pada kategori tinggi. Adapun presentasenya sebagaimana pada tabel di atas yakni sebanyak 23 siswa atau sebesar $41.82 \%$ dari jumlah responden secara keseluruhan yang berjumlah 55 siswa.

Adapun penyajian data dalam bentuk grafik sebagai berikut:

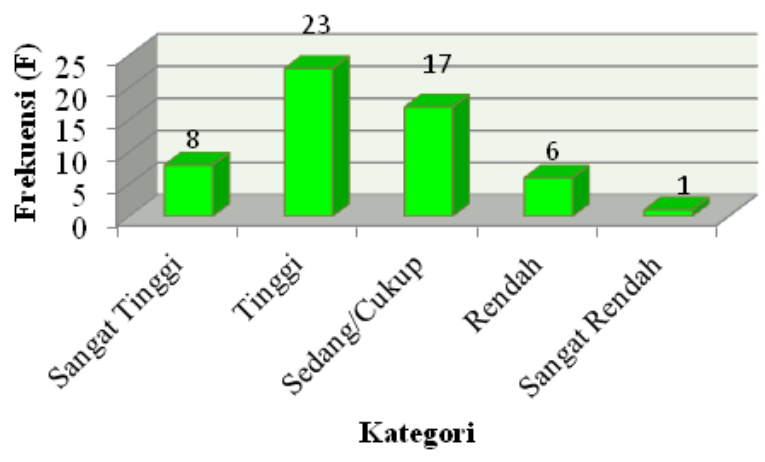

Gambar 3. Grafik Kreativitas Guru

\section{Lingkungan Belajar Siswa}

Lingkungan Fisik

Tanggapan dari siswa kelas III MIN Jejeran terhadap indikator ini adalah seperti pada Tabel 18.

Tabel 18 menunjukkan bahwa pada pernyataan positif $45,45 \%$ responden menjawab jarang menggunakan lingkungan fisik sekolah yaitu siswa jarang menggunakan sarana dan prasarana sekolah, dalam konteks ini adalah mengunjungi perpustakaan sekolah dikarenakan perpustakaan terdapat di MIN Jejeran kampus 1 sedangkan kelas III berada di kampus 2 . Selain itu sekolah jarang mengadakan kerja bakti untuk menjaga kebersihan lingkungan sekolah. Sekolah mengadakan kerja bakti saat terdapat kegiatan-kegiatan khusus misalnya diadakannya lomba antar kelas, sebelum ujian semester, sebelum penerimaan rapot atau sebelum liburan semesteran. Sedangkan untuk pernyataan lingkungan fisik yang berbentuk negatif yaitu lingkungan sekolah bising dengan adanya kendaraan yang lewat menunjukkan $47,27 \%$ responden menjawab tidak pernah. Artinya bahwa lingkungan sekolah tidak bising/ cukup tenang sehingga suasana sekolah kondusif untuk kegiatan belajar mengajar. Semua itu karena letak kelas III berada di sekeliling sawah atau tidak dekat dengan jalan raya.

\section{Lingkungan sosial}

Tanggapan dari siswa kelas III MIN Jejeran terhadap indikator ini adalah sebagai berikut:

Tabel 19. Lingkungan Sosial

\begin{tabular}{|c|c|c|c|c|}
\hline Pernyataan & $\begin{array}{l}\text { No. } \\
\text { Item }\end{array}$ & $\begin{array}{c}\text { Alternatif } \\
\text { Jawaban }\end{array}$ & Frekuensi & $\begin{array}{c}\text { Persentase } \\
(\%)\end{array}$ \\
\hline \multirow{4}{*}{ Positif } & \multirow{4}{*}{4,5} & Selalu & 34 & $30.91 \%$ \\
\hline & & Kadang-kadang & 44 & $40 \%$ \\
\hline & & Jarang & 11 & $10 \%$ \\
\hline & & Tidak pernah & 21 & $19.09 \%$ \\
\hline \multicolumn{3}{|c|}{ Jumlah } & 110 & $100 \%$ \\
\hline
\end{tabular}

Lingkungan sosial meliputi relasi antara siswa dengan siswa dan relasi antara siswa dengan guru atau staf sekolah. Dari tabel di atas menunjukkan bahwa $40 \%$ responden menjawab kadang-kadang. Artinya siswa kadangkadang bermain dengan siswa lain di lapangan sekolah, selebihnya siswa sering menghabiskan waktu istirahat di dalam kelas. Terkadang siswa berbincang dengan guru atau staf sekolah di luar jam pelajaran. Siswa biasanya menceritakan kegiatannya di rumah atau menceritakan perilaku teman-temannya saat berada di sekolah maupun di rumah.

\section{Lingkungan Akademis}

Tanggapan dari siswa kelas III MIN Jejeran terhadap indikator ini adalah sebagai berikut:

Tabel 20. Lingkungan Akademis

\begin{tabular}{|c|c|c|c|c|}
\hline Pernyataan & $\begin{array}{l}\text { No. } \\
\text { Item }\end{array}$ & $\begin{array}{c}\text { Alternatif } \\
\text { Jawaban }\end{array}$ & Frekuensi & $\begin{array}{c}\text { Persentase } \\
(\%)\end{array}$ \\
\hline \multirow{4}{*}{ Positif } & \multirow{4}{*}{6} & Selalu & 13 & $23.63 \%$ \\
\hline & & Kadang-kadang & 29 & $52.72 \%$ \\
\hline & & Jarang & 8 & $14.55 \%$ \\
\hline & & Tidak pernah & 5 & $9.10 \%$ \\
\hline \multicolumn{3}{|c|}{ Jumlah } & 55 & $100 \%$ \\
\hline
\end{tabular}


Lingkungan akademis dalam penelitian ini adalah suasana kegiatan belajar mengajar. Dari tabel diatas 52,72\% responden menjawab kadangkadang yaitu siswa terkadang menjaga ketenangan kelas saat kegiatan pembelajaran berlangsung. Siswa kadang-kadang ramai di dalam kelas. Namun ramainya siswa masih dapat dikondisikan oleh guru.

Dari ketiga indikator di atas dapat disimpulkan bahwa lingkungan belajar memiliki nilai persentasi tertinggi sebagai berikut:

Tabel 21. Persentase Lingkungan Belajar

\begin{tabular}{llc}
\hline \multicolumn{1}{c}{ Indikator } & Jawaban & Persentase \\
\hline a. Lingkungan Fisik & Kadang-kadang & $45.45 \%$ \\
b. Lingkungan Sosial & Kadang-kadang & $40 \%$ \\
c. Lingkungan Akademis & Kadang-kadang & $52.72 \%$ \\
\hline
\end{tabular}

Variabel lingkungan belajar dapat dikelompokkan dalam 5 patokan kategori sesuai dengan norma skala lima sebagai berikut:

\begin{tabular}{|c|c|}
\hline Mean $+1.5 \mathrm{SD}$ & $\begin{array}{l}\text { Sangat tinggi } \\
\begin{aligned}=16.11+ & (1.5 \times 2.740)=20.22 \\
& (\text { Dibulatkan menjadi } 20)\end{aligned}\end{array}$ \\
\hline Mean $+0.5 \mathrm{SD}$ & $\begin{array}{l}\text { Tinggi } \\
\begin{aligned}=16.11+ & (0.5 \times 2.740)=17.48 \\
& (\text { Dibulatkan menjadi } 17)\end{aligned}\end{array}$ \\
\hline Mean - 0.5 SD & $\begin{array}{l}\text { Sedang } \\
=16.11-(0.5 \times 2.740)=14.74 \\
\\
(\text { Dibulatkan menjadi } 14)\end{array}$ \\
\hline Mean - 1.5 SD & $\begin{array}{l}\text { Rendah } \\
=16.11-(1.5 \times 2.740)=12 \\
\quad(\text { Dibulatkan menjadi 12) }\end{array}$ \\
\hline
\end{tabular}

Sehingga diperoleh data sebagai berikut:

Tabel 22. Kategori Lingkungan Belajar

\begin{tabular}{ccc}
\hline Kategori & Rentangan Skor & Pembulatan \\
\hline Sangat Tinggi & $20.22-22.00$ & $20-22$ \\
Tinggi & $17.48-20.21$ & $17-19$ \\
Sedang/Cukup & $14.74-17.47$ & $14-16$ \\
Rendah & $12.00-14.73$ & $12-13$ \\
Sangat Rendah & $10.00-12.00$ & $10-11$ \\
\hline
\end{tabular}

Berdasarkan kategori tersebut, data variabel lingkungan belajar kelas III MIN Jejeran Bantul dapat dilihat pada Tabel 23.

Mean (nilai rata-rata) lingkungan belajar MIN Jejeran Bantul adalah 16.11. Nilai tersebut jika diinterpretasikan pada tabel 13, maka lingkungan belajar MIN Jejeran berada pada
Tabel 23. Rekapitulasi Kategori Lingkungan Belajar

\begin{tabular}{clcc}
\hline No & Kategori & Frekuensi $(\mathrm{F})$ & Persentase $(\%)$ \\
\hline 1 & Sangat Tinggi & 7 & $12.73 \%$ \\
2 & Tinggi & 17 & $30.91 \%$ \\
3 & Sedang/Cukup & 21 & $38.18 \%$ \\
4 & Rendah & 8 & $14.54 \%$ \\
5 & Sangat Rendah & 2 & $3.64 \%$ \\
\hline Total & & 55 & $100 \%$ \\
\hline
\end{tabular}

kategori sedang/cukup. Adapun presentasenya sebagaimana pada tabel di atas yakni sebesar $38.18 \%$ dari jumlah responden secara keseluruhan yang berjumlah 55 siswa.

Adapun penyajian data dalam bentuk grafik sebagai berikut:

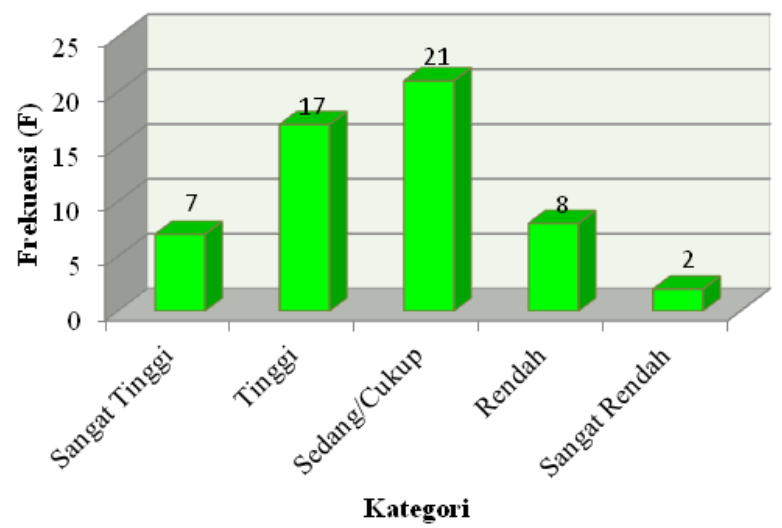

Gambar 4. Grafik Lingkungan Belajar

\section{Keaktifan Siswa}

Listening Activities

Tanggapan dari siswa kelas III MIN Jejeran terhadap indikator ini adalah sebagai berikut:

Tabel 24. Listening Activities

\begin{tabular}{|c|c|c|c|c|}
\hline Pernyataan & $\begin{array}{l}\text { No. } \\
\text { Item }\end{array}$ & $\begin{array}{c}\text { Alternatif } \\
\text { Jawaban }\end{array}$ & Frekuensi & $\begin{array}{c}\text { Persentase } \\
(\%)\end{array}$ \\
\hline \multirow{5}{*}{ Positif } & \multirow{5}{*}{1} & Selalu & 35 & $63.64 \%$ \\
\hline & & Kadang-kadang & 19 & $34.54 \%$ \\
\hline & & Jarang & 0 & $0 \%$ \\
\hline & & Tidak pernah & 1 & $1.82 \%$ \\
\hline & & Jumlah & 55 & $100 \%$ \\
\hline \multirow{5}{*}{ Negatif } & \multirow{5}{*}{2} & Selalu & 1 & $1.82 \%$ \\
\hline & & Kadang-kadang & 24 & $43.64 \%$ \\
\hline & & Jarang & 13 & $23.64 \%$ \\
\hline & & Tidak pernah & 17 & $30.90 \%$ \\
\hline & & Jumlah & 55 & $100 \%$ \\
\hline
\end{tabular}

Tabel di atas menunjukkan bahwa pada pernyataan positif, $63,64 \%$ responden selalu 
melakukan listening activities yakni siswa selalu konsentasi dan memperhatikan saat guru menjelaskan materi. Pada pernyataan negatif 43.64\% responden menjawab kadang-kadang. Artinya kadang-kadang siswa mengobrol dengan teman saat guru menjelaskan materi.

\section{Oral Activities}

Tanggapan dari siswa kelas III MIN Jejeran terhadap indikator ini adalah sebagai berikut:

Tabel 25. Oral Activities

\begin{tabular}{|c|c|c|c|c|}
\hline Pernyataan & $\begin{array}{l}\text { No. } \\
\text { Item }\end{array}$ & $\begin{array}{c}\text { Alternatif } \\
\text { Jawaban }\end{array}$ & Frekuensi & $\begin{array}{c}\text { Persentase } \\
(\%)\end{array}$ \\
\hline \multirow{4}{*}{ Positif } & \multirow{4}{*}{3,6} & Selalu & 42 & $38.18 \%$ \\
\hline & & Kadang-kadang & 51 & $46.36 \%$ \\
\hline & & Jarang & 13 & $11.82 \%$ \\
\hline & & Tidak pernah & 4 & $3.64 \%$ \\
\hline \multicolumn{3}{|c|}{ Jumlah } & 55 & $100 \%$ \\
\hline
\end{tabular}

Tabel di atas menunjukkan $46.36 \%$ siswa melakukan oral activities yaitu siswa selalu bertanya kepada guru apabila siswa mengalami kesulitan saat pembelajaran. Guru selalu memberikan kesempatan kepada siswa untuk bertanya kepada guru dan guru selalu memberikan tanggapan atau membantu siswa saat kesulitan. Selain itu, saat guru mengadakan diskusi kelompok siswa antusias dalam berpendapat saat diskusi.

\section{Emotional Activities}

Tanggapan dari siswa kelas III MIN Jejeran terhadap indikator ini adalah sebagai berikut:

Tabel 26. Emotional Activities

\begin{tabular}{|c|c|c|c|c|}
\hline Pernyataan & $\begin{array}{l}\text { No. } \\
\text { Item }\end{array}$ & $\begin{array}{c}\text { Alternatif } \\
\text { Jawaban }\end{array}$ & Frekuensi & $\begin{array}{c}\text { Persentase } \\
(\%)\end{array}$ \\
\hline \multirow{5}{*}{ Positif } & \multirow{5}{*}{4} & Selalu & 18 & $32.73 \%$ \\
\hline & & Kadang-kadang & 29 & $52.73 \%$ \\
\hline & & Jarang & 7 & $12.73 \%$ \\
\hline & & Tidak pernah & 1 & $1.81 \%$ \\
\hline & & Jumlah & 55 & $100 \%$ \\
\hline \multirow{5}{*}{ Negatif } & \multirow{5}{*}{5} & Selalu & 2 & $3.63 \%$ \\
\hline & & Kadang-kadang & 5 & $9.09 \%$ \\
\hline & & Jarang & 16 & $29.09 \%$ \\
\hline & & Tidak pernah & 32 & $58.18 \%$ \\
\hline & & Jumlah & 55 & $100 \%$ \\
\hline
\end{tabular}

Tabel di atas menunjukkan bahwa pada pernyataan positif $52,73 \%$ responden kadangkadang melakukan Emotional activities yakni antusias dalam mengikuti pelajaran yaitu dengan membantu teman yang mengalami kesulitan saat pelajaran. Sedangkan untuk pernyataan negatif, $58.18 \%$ responden menjawab tidak pernah mencontek saat mengerjakan tugas dari guru.

\section{Mental Activities}

Tanggapan dari siswa kelas III MIN Jejeran terhadap indikator ini adalah sebagai berikut:

Tabel 27. Mental Activities

\begin{tabular}{|c|c|c|c|c|}
\hline Pernyataan & $\begin{array}{l}\text { No. } \\
\text { Item }\end{array}$ & $\begin{array}{c}\text { Alternatif } \\
\text { Jawaban }\end{array}$ & Frekuensi & $\begin{array}{c}\text { Persentase } \\
(\%)\end{array}$ \\
\hline \multirow{5}{*}{ Positif } & \multirow{5}{*}{7} & Selalu & 18 & $32.72 \%$ \\
\hline & & Kadang-kadang & 30 & $54.94 \%$ \\
\hline & & Jarang & 5 & $9.09 \%$ \\
\hline & & Tidak pernah & 2 & $3.63 \%$ \\
\hline & & Jumlah & 55 & $100 \%$ \\
\hline \multirow{5}{*}{ Negatif } & \multirow{5}{*}{8} & Selalu & 3 & $5.44 \%$ \\
\hline & & Kadang-kadang & 16 & $29.10 \%$ \\
\hline & & Jarang & 16 & $29.10 \%$ \\
\hline & & Tidak pernah & 20 & $36.36 \%$ \\
\hline & & Jumlah & 55 & $100 \%$ \\
\hline
\end{tabular}

Tabel di atas menunjukkan bahwa pada pernyataan positif $54,94 \%$ responden selalu melakukan mental activities yakni siswa dapat memecahkan masalah atau menjawab pertanyaan yang diberikan oleh guru. Sedangkan pada pernyataan negatif $36.36 \%$ responden tidak pernah membuat kegaduhan atau rami di kelas.

Writing Activities

Tanggapan dari siswa kelas III MIN Jejeran terhadap indikator ini adalah sebagai berikut:

Tabel 28. Writing Activities

\begin{tabular}{|c|c|c|c|c|}
\hline Pernyataan & $\begin{array}{l}\text { No. } \\
\text { Item }\end{array}$ & $\begin{array}{l}\text { Alternatif } \\
\text { Jawaban }\end{array}$ & Frekuensi & $\begin{array}{c}\text { Persentase } \\
(\%)\end{array}$ \\
\hline \multirow{4}{*}{ Positif } & \multirow{4}{*}{9} & Selalu & 18 & $32.72 \%$ \\
\hline & & Kadang-kadang & 21 & $38.18 \%$ \\
\hline & & Jarang & 8 & $14.55 \%$ \\
\hline & & Tidak pernah & 8 & $14.55 \%$ \\
\hline \multicolumn{3}{|c|}{ Jumlah } & 55 & $100 \%$ \\
\hline
\end{tabular}

Tabel di atas menunjukkan 38,18\% siswa selalu melakukan writing activities yaitu siswa aktif merangkum/ mencatat materi yang dijelaskan oleh guru.

Dari kelima indikator di atas dapat disimpulkan bahwa keaktifan siswa memiliki nilai 
persentasi tertinggi sebagai berikut:

Tabel 29. Persentase Keaktifan Belajar Siswa

\begin{tabular}{llc}
\hline \multicolumn{1}{c}{ Indikator } & \multicolumn{1}{c}{ Jawaban } & Persentase \\
\hline a. Listening Activities & Selalu & $63.64 \%$ \\
b. Oral Activities & Kadang-kadang & $43,36 \%$ \\
c. Emotional Activities & Kadang-kadang & $52.73 \%$ \\
d. Mental Activities & Kadang-kadang & $54.94 \%$ \\
e. Writing Activities & Selalu & $38.18 \%$ \\
\hline
\end{tabular}

Variabel keaktifan siswa dapat dikelompokkan dalam 5 patokan kategori sesuai dengan norma skala lima sebagai berikut:

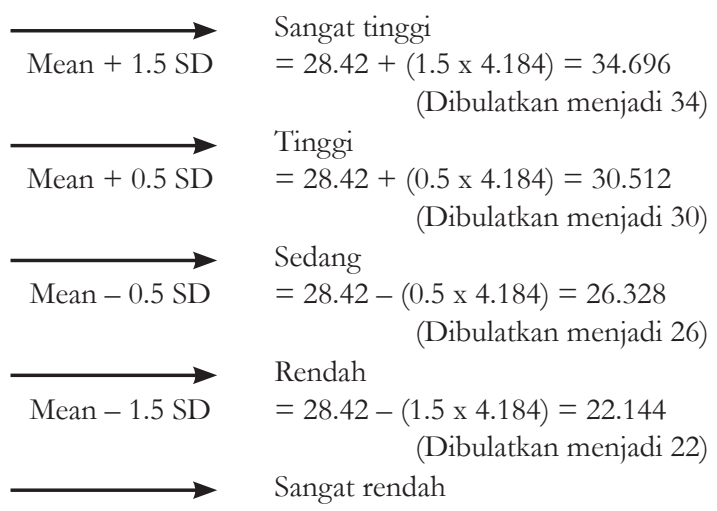

Sehingga diperoleh data sebagai berikut:

Tabel 30. Kategori Keaktifan Siswa

\begin{tabular}{ccc}
\hline Kategori & Rentangan Skor & Pembulatan \\
\hline Sangat Tinggi & $34.70-36.00$ & $34-36$ \\
Tinggi & $30.51-34.69$ & $30-33$ \\
Sedang/Cukup & $26.33-30.50$ & $26-29$ \\
Rendah & $22.14-26.32$ & $22-25$ \\
Sangat Rendah & $16.00-22.14$ & $16-21$ \\
\hline
\end{tabular}

Berdasarkan kategori tersebut, data variabel lingkungan belajar kelas III MIN Jejeran Bantul yaitu sebagai berikut:

Tabel 31. Kategori Keaktifan Siswa

\begin{tabular}{clcc}
\hline No & Kategori & Frekuensi $(\mathrm{F})$ & Persentase $(\%)$ \\
\hline 1 & Sangat Tinggi & 7 & $12.73 \%$ \\
2 & Tinggi & 16 & $29.09 \%$ \\
3 & Sedang/Cukup & 19 & $34.54 \%$ \\
4 & Rendah & 11 & $20 \%$ \\
5 & Sangat Rendah & 2 & $3.64 \%$ \\
\hline Total & & 55 & $100 \%$ \\
\hline
\end{tabular}

Tabel 32. Hasil Analisis Data

\begin{tabular}{|c|c|c|c|c|}
\hline \multicolumn{5}{|c|}{ Correlations } \\
\hline & & $\begin{array}{l}\text { Kreativitas } \\
\text { guru }\end{array}$ & $\begin{array}{l}\text { Lingk. } \\
\text { Belajar }\end{array}$ & $\begin{array}{c}\text { Keaktifan } \\
\text { siswa }\end{array}$ \\
\hline \multirow[t]{3}{*}{$\begin{array}{l}\text { kreativitas_ } \\
\text { guru }\end{array}$} & $\begin{array}{l}\text { Pearson } \\
\text { Correlation }\end{array}$ & 1 & $.336^{*}$ & $.356^{* *}$ \\
\hline & Sig. (2-tailed) & & .012 & .008 \\
\hline & $\mathrm{N}$ & 55 & 55 & 55 \\
\hline lingk_Belajar & $\begin{array}{l}\text { Pearson } \\
\text { Correlation }\end{array}$ & $.336^{*}$ & 1 & $.379^{* *}$ \\
\hline \multirow[t]{2}{*}{ Sig. (2-tailed) } & & .012 & & .004 \\
\hline & $\mathrm{N}$ & 55 & 55 & 55 \\
\hline \multirow[t]{3}{*}{$\begin{array}{l}\text { keaktifan_ } \\
\text { siswa }\end{array}$} & $\begin{array}{l}\text { Pearson } \\
\text { Correlation }\end{array}$ & $.356^{* *}$ & $.379^{* *}$ & 1 \\
\hline & Sig. (2-tailed) & .008 & .004 & \\
\hline & $\mathrm{N}$ & 55 & 55 & 55 \\
\hline
\end{tabular}

*. Correlation is significant at the 0.05 level

(2-tailed).

**. Correlation is significant at the 0.01 level

(2-tailed).

Mean (nilai rata-rata) keaktifan siswa kelas III MIN Jejeran Bantul adalah 28.42. Nilai tersebut jika diinterpretasikan pada tabel 20, maka keaktifan siswa kelas III MIN Jejeran berada pada kategori sedang/cukup. Adapun presentasenya sebagaimana pada tabel di atas yakni sebesar $34.54 \%$ dari jumlah responden secara keseluruhan yang berjumlah 55 siswa.

Adapun penyajian data dalam bentuk grafik sebagai berikut:

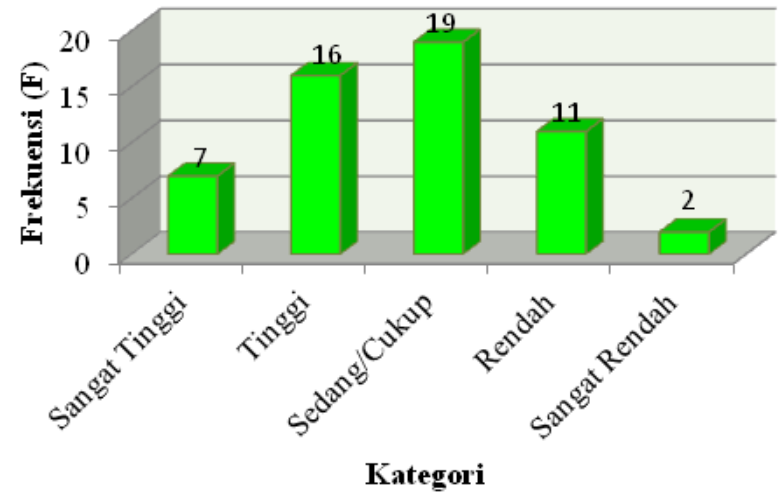

\section{Gambar 5. Grafik Keaktifan Siswa}

Tabel 32 menunjukkan bahwa nilai korelasi yang diperoleh sebagai berikut:

a. Kreativitas guru dengan keaktifan siswa memiliki korelasi sebesar 0.356 
b. Lingkungan belajar dengan keaktifan siswa memiliki korelasi sebesar 0.379

c. Kreativitas guru dengan lingkungan belajar memiliki korelasi sebesar 0,336

\section{PEMBAHASAN}

Hubungan Kreativitas Guru dan Lingkungan Belajar dengan Keaktifan Siswa

Tabel 33. Hasil Analisis Regresi

\begin{tabular}{cc}
\hline Model & $\mathrm{R}$ \\
\hline 1 & $.450^{*}$ \\
\hline
\end{tabular}

Dari hasil penelitian dan analisis data yang dilakukan, diperoleh kesimpulan bahwa terdapat hubungan yang positif antara variabel X1 (Kreativitas Guru), variabel X2 (Lingkungan Belajar), dan variabel Y (keaktifan siswa) di MIN Jejeran Bantul.

Dari beberapa teori yang telah dikemukakan sebelumnya dan hasil analisis regresi, jika dihubungkan dengan hasil penelitian yang mengukur korelasi antara kreativitas guru, lingkungan belajar dan keaktifan siswa menghasilkan angka " $\mathrm{r}$ " hitung 0.450 , sehingga apabila " $r$ " hitung terdapat di kisaran 0,40-0,599 maka dikategorikan dalam tingkatan hubungan yang cukup kuat. Hal ini menunjukkan adanya kesesuaian antara teori dengan hasil penelitian. Hubungan kreativitas guru dan lingkungan belajar terhadap keaktifan siswa di MIN jejeran bantul tergolong cukup kuat. Kontribusi secara simultan dan sisanya ditentukan oleh variabel lainnya.

Sesuai dengan pendapat Muhibbin bahwa faktor yang mempengaruhi keaktifan siswa terdiri dari 3 aspek, yaitu faktor internal, eksternal dan pendekatan belajar. Variabel kreativitas guru dan lingkungan belajar merupakan bagian dari faktor eksternal. Kedua variabel tersebut berkontribusi sebesar 20,25\% terhadap keaktifan siswa, sedangkan sisanya yaitu 79,75\% dipengaruhi oleh variabel lain yang menjadi bagian dari ketiga faktor yang tidak masuk dalam penelitian ini.

Angka $\mathrm{r}$ hitung $=0.450$ mengandung arti bahwa korelasi antara kreativitas guru, lingkungan belajar dan keaktifan siswa adalah korelasi yang positif (searah), yakni apabila kreativitas guru meningkat dan lingkungan belajar memadai maka keaktifan siswa juga meningkat. Apabila kreativitas guru menurun dan lingkungan belajar tidak memadai maka keaktifan siswa juga ikut menurun.

Nilai "r" product moment apabila dikonsultasikan dengan $\mathrm{N}$ sebesar 55 dengan taraf sigfikansi $5 \%$ yaitu memiliki nilai 0.266 . Sehingga $r$ hitung memiliki nilai lebih besar daripada $r$ tabel yakni $0.450>0.266$. Dengan demikian, berdasarkan hasil perhitungan diketahui bahwa Ho ditolak dan Ha diterima, yang berarti terdapat korelasi antara kreativitas guru (X1) dan lingkungan belajar (X2) dengan keaktifan siswa (Y) siswa kelas III MIN Jejeran Bantul.

\section{PENUTUP}

Sebagai akhir dari rangkaian penelitianyang berjudul "Hubungan Kreativitas Guru dan Lingkungan Belajar terhadap Keaktifan Siswa Kelas III MIN Jejeran Bantul Tahun Ajaran 2015/2016" dengan mengacu pada data yang telah terkumpul dan setelah data tersebut di analisis, maka penulis menyusun kesimpulan sebagai berikut:

Kreativitas Guru dan Lingkungan Belajar memiliki hubungan dengan Keaktifan Siswa Kelas III di MIN Jejeran yang tergolong cukup kuat. Terbukti bahwa dengan angka " $r$ " hitung kreativitas guru dan lingkungan belajar terhadap keaktifan siswa yaitu 0.450 , sehingga apabila " $\mathrm{r}$ " hitung terdapat di kisaran 0,40 - 0,599 maka dikategorikan dalam tingkatan hubungan yang cukup kuat dengan kontribusi simultan sebesar $20,25 \%$ dan sisanya dipengaruhi oleh variabel lainnya.

Apabila dikonsultasikan pada nilai "r" product moment, dengan $\mathrm{N}$ sebesar 55 dengan taraf sigfikansi 5\% yaitu memiliki nilai 0,266. Sehingga r hitung lebih besar daripada $r$ tabel yakni 0,450 $>0,266$. Dengan demikian, berdasarkan hasil perhitungan diketahui bahwa Ho ditolak dan $\mathrm{Ha}$ diterima, berarti terdapat korelasi yang positif antara kreativitas guru (X1) dan lingkungan belajar (X2) dengan keaktifan siswa (Y) siswa kelas III MIN Jejeran Bantul. 


\section{DAFTAR PUSTAKA}

A Samana. 1994. Profesionalisme Keguruan. Yogyakarta: Kanisius

Ali Imron. 1995. Pembinaan Guru di Indonesia. Jakarta: Pustaka Jaya

Anas Sudijono. 1996. Pengantar Evaluasi Pendidikan. Jakarta: PT Raja Grafindo Persada

Bahasa Mahasiswa. 2011. Undang-Undang Sistem Pendidikan. http://bahasamahasiswa.blogspot.co.id/2011/01/undangundangsisdiknas-sistem.html, diunduh pada hari selasa 01 september pukul 11:40

Cece Wijaya. 1988. Upaya Pembaharuan dalam Pendidikan dan Pengajaran. Bandung: Remaja Karya

Chalijah Hasan. 1994. Dimensi-Dimensi Psikologi Pendidikan. Surabaya: Al Ikhlas

Debdikbud. 1995. Kamus Besar Bahasa Indonesia. Jakarta: Balai Pustaka

Devamelodica. 2012. Contoh Proposal Skripsi Pendidikan Pengaruh Lingkungan Sekolah, Peran Guru dalam Proses Pembelajaran terhadap Motivasi Belajar Siswa, http:// devamelodica.com/contoh-proposal-skripsipendidikan-pengaruh-lingkungan-sekolahperan-guru-dalam-proses-pembelajaranterhadap-motivasi-belajar-siswa/, diunduh Minggu, 3 Oktober 2015

E Mulyasa. 2009. Menjadi Kepala Sekolab Profesional. Bandung: PT Remaja Rosdakarya Irwanto. 2012. Komputasi Data Statistik Untuk Penelitian, (Pengolahan dan Analisis Data Penelitian dengan Ms Excel dan SPSS. Yogyakarta: CV Budi Utama
Iskandara Agung. 2010. Meningkatkan Kreativitas Pembelajaran Bagi Guru. Jakarta: Bestari Buana Murni

Peter Salim dan Yeni Salim. 1991. Kamus Besar Kontemporer, Edisi Pertama. Jakarta: Modern English Press

Riduwan dkk. 2011. Pengantar Statistika Untuk Penelitian: Pendidikan, Sosial,

Komunikasi, Ekonomi dan Bisnis. Bandung: Alfabeta Sardiman. 2007. Interaksi Belajar Mengajar. Jakarta: PT. Raja Grafindo Persada

Slameto. 2003. Belajar dan faktor-faktor yang mempengarubinya. Jakarta: PT Asdi Mahastya

Sugiyono. 2010. Statistik Untuk Pendidikan. Bandung: Alfabeta

Suharsimi Arikunto. 1989. Dasar-Dasar Evaluasi Pendidikan. Jakarta: CV Rajawali 2010. Prosedur Penelitian Ilmiah

Suatu Pendekatan Praktek. Jakarta: PT. Rineka Cipta

Syaiful Bahri Djamarah. 2000. Guru dan Anak Didik dalam Interaksi Edukatif. Jakarta: Rineka Cipta

Udin Syaefudin Saud. 2011. Pengembangan Profesi Guru. Bandung: Alfabeta

Utami Munandar. 1986. Mengembangkan Bakat dan Kreativitas Anak Sekolab; Petunjuk BagiPara Guru dan Orang Tua. Jakarta: Gramedia

Wiji Sumarno. 2006. Dasar-Dasar Ilmu Pendidikan. Yogyakarta: Ar-Ruz Media

Wina Sanjaya. 2006. Strategi Pembelajaran Berorientasi Standar Proses Pendidikan. Jakarta: Kencana

Zakiyah Darajat, dkk. 1996. Ilmu Pendidikan Islam. Jakarta: Bumi aksara 